\title{
THE PERCEIVED LEVELS OF INTOLERANCE FOR PRESS CRITICISM IN PAKISTANI SOCIETY
}

\author{
Fazli Hussain* \\ Noreen Aleem ${ }^{* \square}$ \\ Samreen Faisal***
}

\begin{abstract}
This study examines the existence, intensity and impacts of intolerance for Press criticism in Pakistani society. It's generally believed that intolerance for Press criticism leads to professional and psychological complexes for the Press to play its role as a voice for unvoiced and to hold those in power accountable because the Press's role as the Watchdog compulsively needs high capacities of tolerance in the society to understand the realities and habituate rationalism. As working journalists have to face the direct reaction from masses regarding Press criticism so this paper explores journalist's perceptions about the presence of intolerance in the societal frame of Pakistan regarding Press's criticism using survey technique under Likert Scale. The study also incorporates the impacts of intolerance on professionalism in media that induce threats to journalists and compel them to exercise self-censorship which ultimately results in content biases, depriving the citizens of fundamental right of expression. The conclusion provides guidelines for policy making on the subject of Press freedom and social coherence. Also, this study enhances understandings regarding the social sphere of the country and gauges the level of intolerance for media discourses.
\end{abstract}

Keywords: Social intolerance; Pakistani society; press criticism; freedom of expression; self-censorship; threats to journalists

\section{Introduction}

Quaid-e-Azam Muhammad Ali Jinnah said while addressing in Imperial Legislative Council on Sept 19; 1948 "I say; protect the innocent; protect those journalists who are doing their duty and who are serving both the public and the Government by criticizing the Government freely; independently; honestly which is an education for any Government". Similarly; replying to the welcome address at Edward College in Peshawar on Apr 18; 1948; he clarified "I want you to keep your heads up as citizens of a free and independent sovereign State. Praise your Government when it deserves. Criticize your Government fearlessly when it deserves; but do not go on all the time attacking; indulging

\footnotetext{
This work is Licensed under a Creative Commons Attribution-Non-Commercial 4.0 International License. (c) (1) (9)

Fazli Hussain, Ph.D. Assistant Professor Department of Media Studies. ILMA University Karachi.

$\square$ Noreen Aleem, Ph.D. Assistant Professor Department of Media Studies Sindh Madressatul Islam University Karachi

*** Samreen Faisal, Research Scholar, Department of Mass Communication, Federal Urdu University of Atrs, Science and Technology (FUUAST) Karachi
} 
in destructive criticism; taking delight in running down the Ministry or the officials"1. These quotes make it easy to understand that objectivity and unbiased content is the foremost responsibility of a professional Press but also assert to make it sure that no interruption in the flow of information from source to the target is vital to safeguard the right of expression and that should be guaranteed by the state as well as affirmed by the society. A best reflection of the phenomenon is here in the generally ratified quote "You have freedom to spread hands but not to touch my nose".

Globally; the Press is guaranteed to work free of interference; following professional standards under international instruments but it's also a bitter reality that national interests; friendly relations with foreign states and restrictions by laws are allowed to constraint the professional limits. Similarly; the Pressure for political communications and the economic dependency of Press on the governments and society also subjugate the professional heights to polarizations which provides ground to intolerance for Press criticism.

Within the parameters of rights and responsibilities; laid down in the article 19 of The Universal Declaration of Human Rights $1948^{2}$ and the article 19 and 19A of the Constitution of Pakistan 1973'; freedom of Press is the sacred duty to disseminate true; impartial and unbiased information to the audiences; readers and viewers. But there are reported hurdles in the flow of information including social intolerance; partisan journalism; governmental and nongovernmental interests' groups; ownership's monetary interests; religious group's Pressure; political and other influential personnel 's intervention for personal and political gains etc; which make the whole of the media environment multifarious and malicious.

Respectively; the Press system in Pakistan couldn't develop as an integrated entity and always compromised on the professional standards; sometime due to forceful interference from political elites and the governmental departments and sometime due to self-interests of journalist's and media moguls. But mostly such non-professional practices aroused the sentiments of readers and viewers which ended in violence against the Press.

That is why; journalists in Pakistan are exercising self-censorship or following the popular narratives. But the assumption remains unaddressed that impartiality; objectivity and unbiased Press is a guarantee to the development of standard democratic norms and values for a more transparent society.

Addressing the ground realities of the Press professionalism and the cultural pattern of the society; it's important to engage the working journalists in the study so that this study

\footnotetext{
${ }^{1}$ Quotes from Qaid-e-Azam Muhammad Ali Jinnah. Retrieved on October 08, 2020. From, http://nazariapak.info/Quaid-e-Azam/Qoutes.php

${ }^{2}$ Universal Declaration of Human Rights (1948). Retrieved on October 09, 2020. From, https://www.un.org/en/universal-declaration-human-rights/

${ }^{3}$ Constitution of Pakistan 1973, Chapter 1, article 19, 19A. Retrieved on October 09, 2020. From, http://www.na.gov.pk/uploads/documents/1333523681_951.pdf
} 
is focused on prevailing intolerance for Press criticism in the society which is the most pertinent aspect that affects the professional objectivity of the Press.

\section{Literature review}

Social intolerance is a consequence; not a cause ${ }^{4}$ but if the sentimental attachment is governed by wisdom and reason the level would unquestionably be diminished and consequently no limits of decencies would be crossed because tolerance is the propound consequence of rationalism which negates the emergence of rough and negative sentimental ties and nib extremism in the bud. Societies; where no place is there for extremism; they are based on high rationalism; also there flourish towering values of democracy and brilliant democratic and humanistic values ${ }^{5}$.

Although; freedom of expression is guaranteed in the constitution of Pakistan (1973) but as a recognized reality; there are always some open and implied restrictions that confine it. No society permits absolute freedom nor a government; organizations and even individuals allow criticism under open debates ${ }^{6}$.

Pakistan is ranked by Freedom House (FH) as "partly free" in the category of Global Freedom while "Not Free" in the category of Internet Freedom? societies around the world are being governed by sophisticated smooth behavior of tolerance for Press criticism; surely; not because resistance to some approaches is quite natural and that is witnessed ${ }^{8}$. Similarly; the press freedom is typically considered as central to the development of high democratic values but the partisan media and nonprofessional Press can also ignite and fuel social intolerance ${ }^{9}$. Likely; the sociology of Press and idealistic consent of Press criticism to play the role as "Watchdog" and "agenda setting" under the Normative doctrines; is mandatory to be free of partisan curses.

Although; the Press criticism is essential to democratic processing but It's evident that most of the countries; even the developed democracies of the world lack formal structural mechanism and tradition for Press criticism ${ }^{10}$.

\footnotetext{
${ }^{4}$ Chiara V, Ramon Portugal F, Jeanson R "Social intolerance is a consequence, not a cause, of dispersal in spiders". (2019) PLoS Biol 17(7): e3000319. Retrieved on October 11, 2020. From, https://doi.org/10.1371/journal.pbio.3000319

${ }^{5}$ Harrison G. Gough "Studies of Social Intolerance: I. Some Psychological and Sociological Correlates of Anti-Semitism, The Journal of Social Psychology", (1951) 33:2, 237-246, DOI: 10.1080/00224545.1951.9921815

${ }^{6}$ Gunaratne, Shelton A. "The Media in Asia: An Overview." Gazette (Leiden, Netherlands) 61, no. 3-4 (July 1999): 197-223. https://doi.org/10.1177/0016549299061003002.

${ }^{7}$ Freedom House. Retrieved on October11, 2020.from, https://freedomhouse.org/countries/freedomworld/scores

${ }^{8}$ Hussain, Fazal. "Gender Discrimination in Media As Workplace: A Study of Media Environment in Sindh". Pakistan Journal of Gender Studies 18, no. 1 (March 8, 2019): 23-42. From, https://www.socialsciencejournals.pjgs-ws.com/index.php/PJGS/article/view/23. (Accessed October 4, 2020) ${ }^{9}$ Hutchison, Marc L., Salvatore Schiano, and Jenifer Whitten-Woodring. "When the fourth estate becomes a fifth column: The effect of media freedom and social intolerance on civil conflict." The International Journal of Press/Politics 21, no. 2 (2016): 165-187. https://doi.org/10.1177/1940161216632362

${ }^{10}$ Wyatt. Wendy. "Press Criticism" in: The International Encyclopedia of Journalism Studies Online. Retrieved on October 18, 2020.from, https://onlinelibrary.wiley.com/doi/pdf/10.1002/9781118841570.iejs0104
} 
Generally; the role of Press is theorized to serve; raise and channelize the voice for those who have no say in the affairs of their government and also the Press is expected to hold those in power accountable ${ }^{11}$ and for that the Press criticism is pivotal.

It is understandable that in an ideological state like Pakistan; it's not an easy job to be journalist but the global situation is also unfavorable for Press criticism. An open criticism on CNN by the US president is reflecting the high intolerance for Press criticism in USA.

In this regards; the Press history of Pakistan reveals that from time to time the Press and Press personals suffered the consequences of professionalism and this always had led to self-censorship or had given birth to favoritism.

Unfortunately; the society has shown less tolerance for Press criticism on one hand while the non-professional approach of journalists and their political affiliation has made the Press badly biased on the other. Lavarch ${ }^{12}$ declares that the low level of education and partisan approach of media men in Pakistan weaken the freedom of Press. He further denotes that the print and electronic media in Pakistan is openly divided in to political blocks. A part of the Press promotes the political agenda of Pakistan People's Party while some of the journalists are supporting Pakistan Tehreek Insaf while a section of media is trying to favor the Muslim League Nawaz Group. Similarly; a reasonable portion of Press is devoted to advocate the religious parties in the country. In the same lines the owners of the media conglomerates in Pakistan are lured by economic and self-interests whereas their publishing policies are governed by the gains they have already compromised.

In spite of different hindrances; the conventional role of Press criticism as a mirror of the society is vital for the development of positive behavioral changes and for educating the society. Pakistani national Press and working journalists are bravely facing harassments; threats and pressure continuously for last 71 years but still they are devoted to play their role as Watchdogs.

\section{Pakistani Society and Intolerance for Press Criticism}

Pakistani society is highly divergent; linguistically; ethnically; ethologically; regionally and ideologically but still there are enough ties to strengthen the social fabric and empower national integrity. According to the Pakistan Bureau of Statistics the major part of population is Punjabi speaking (44.15) followed by Pashto 15.42; Sindhi (14.1); Saiki (10.53); Urdu (7.57); Balochi (3.57) and 4.66 others $^{13}$. Such a lingual diversity is not really the conflicting factor but the question is whether all the citizens are governed by the same national sentiments which lead to national integrity? Unfortunately; the history in this regard is not encouraging as here is a clear distinction among different lingual

\footnotetext{
${ }^{11}$ Hutchison, Marc L., Salvatore Schiano, and Jenifer Whitten-Woodring. "When the fourth estate becomes a fifth column: The effect of media freedom and social intolerance on civil conflict." The International Journal of Press/Politics 21, no. 2 (2016): 165-187. https://doi.org/10.1177/1940161216632362

${ }^{12}$ Lavarch, M, "Free Speech, Responsible Media, Law and Liberal Democracy", More or Less Democracy \& New Media, (2012)24-49. Retrieved on February 5, 2018, from MoreOrLess-FinalText.x_MoreOrLessFinalText.x (futureleaders.com.au)

${ }^{13}$ Pakistan Bureau of Statistics (2016) ." Population by Mother Tongue". Retrieved on October 14, 2020. From,

http://www.pbs.gov.pk/sites/default/files//tables/POPULATION\%20BY\%20MOTHER\%20TONGUE.pdf
} 
groups and all of them are engaged in open conflicts. One of the undeniable examples is the partition of Pakistan into two halves and the creation of Bangladesh in $1971^{14}$. In the same way; the Urdu Sindhi conflict (the language riots) led to Sindhi Mohajir confrontations in July 1972 which set the province of Sindh ablaze ${ }^{15}$.

Similarly; the sectarian division of Pakistani society also inculcates ideological differences which enhances intolerance for criticism and engraves conflicts that ultimately diverts into extremism. Although; 96.8 percent of the population of Pakistan is Muslims but there are also 1.59 percent Christians; 1.6 percent Hindus; 0.22 percent Qadiani; 0.25 percent Scheduled Castes and 0.07 percent others ${ }^{16}$ but the critical situation is with the groups within the Muslims. There are distinct rivalries among the Shiite; Sunni; Ahl-iHadith; Barelvi; Deobandi etc which sometimes emerges in conflicts ${ }^{17}$; and the most distressed aspect of such differences become visible when it is disseminated by the Press $^{18}$. Moreover; regionalism and separatism has also made its way into the social fabric of Pakistani society. The Baloch; Sindhi and Pashtun nationalities are blaming Punjab for disparities and exploitations of resources and authorities ${ }^{19}$. The gravity increases when intolerance nourishes violence and enrages sentiments ${ }^{20}$.

So the state of affairs regarding the level of tolerance in Pakistani society is not hopeful and the scenario becomes more alarming when such occurrences are reported and disseminated by the Press. Most of threats to journalists and violence against the Press are linked with intolerance for the Press criticism in the country. Karachi Press club ${ }^{21}$ was attacked four times while Peshawar Press Club ${ }^{22}$ was also attacked in the same flow. Also; a number of journalists suffered from the uncontrollable sentimental violence having roots in the intolerance for Press criticism. That is why; Pakistan was declared the dangerous

\footnotetext{
${ }^{14}$ Mustafa.Ghulam \& Nawa.Adil. "The Separation of East Pakistn:Socio-Economic Factors" Asian Journal of Multidisciplinary Studies. Vol 2, issue 1 (2014). Retrieved on October 13, 2020.from, https://www.academia.edu/42789130/Asian_Journal_of_Multidisciplinary_Studies_The_Separation_Of_East_ Pakistan_Socio_Economic_Factors

${ }^{15}$ Daily Dawn. "A leaf from history: Language frenzy in Sindh” Retrieved on Oct 6, 2012. From, https://www.dawn.com/news/754685/a-leaf-from-history-language-frenzy-in-sindh ${ }^{16}$ PBS, "Population by Religion". Retrieved on October 22, 2020. From, http://www.pbs.gov.pk/sites/default/files//tables/POPULATION\%20BY\%20RELIGION.pdf

${ }^{17}$ Daily Dawn, “Sectarian Tensions' . Retrieved on Sep 21, 2020. https://www.dawn.com/news/1580818

${ }^{18}$ Asma and Muhammad,"History of Sectarianism in Pakistan: Implications for Lasting Peace: J Pol Sci Pub Aff 2017, 5:4 , DOI: 10.4172/2332-0761.1000291, https://www.longdom.org/open-access/history-ofsectarianism-in-pakistan-implications-for-lasting-peace-2332-0761-1000291.pdf

${ }^{19}$ Daily Dawn, "50 shades of inequality in Pakistan", (May 14, 2015). Retrieved on October 23, from https://www.dawn.com/news/1178703

${ }^{20}$ Basit. Abdul, , "Pakistan Stock Exchange: New Wave of Ethno-Separatist Violence?, South Asian Journal, (July 17, 2020), Retrieved on Sep 25, 2020 from. http://southasiajournal.net/pakistan-stock-exchange-attacknew-wave-of-ethno-separatist-violence/

${ }^{21}$ The Nation, "Hooligans attack Karachi Press Club".( March 28, 2016). Retrieved on Sep 24, 2020 from https://nation.com.pk/28-Mar-2016/hooligans-attack-karachi-Press-club

${ }^{22}$ Daily Dawn, "Peshawar Press Club Attack (Dec 12, 2009). Retrieved on Oct 24, 2020, from, https://www.dawn.com/news/510394
} 
place for journalism by $\mathrm{CPJ}^{23}$ but irony is that Pakistan got place among the countries where killers of journalists go unpunished ${ }^{24}$.

It's important to note that the government-Press and the Press-society relations in Pakistan is a legacy of British India where the Press was a cardinal part of the politics and journalists were playing the crusading role for the cause of the freedom; from the foreign rule. Syed ${ }^{25}$ declares that in the first decade of Pakistan; the open war among the different sections of the Muslim League gave way to palace intrigues and each section tried to drag the media and journalists in the strife. Further; he notified that the situation induced intolerance in the society for Press criticism as the impartiality and professionalism in the media system was deteriorated by politicization and polarization.

Similarly; the specified interests of the religious and ethnical groups are the areas to be touched with high care. This is the threshold subject from where intolerance for Press criticism results in danger. It's very clear that the national interests; the state's ideology; the social norms and values and the delicate boundaries of cultural fabric; are the subjects which need to be dealt carefully. This is because the history of violence against the Press criticism; has always given rise to killing of journalists in the country; on the basis of religious and ethnical sensations. Generally; the religious and fundamentalist set of minds in the country blame the media for the promotion of liberalism and westernization and use this for the legitimization of their violence to achieve their desired goals. ${ }^{26}$

It's almost proved that journalists in Pakistan are facing terrible situation with respect to security; jobs instability; social reactions etc; but their moral is not down and they are bravely facing the threats and encountering the hurdles with high professional zeal and spirit $^{27}$.

In pursuance of the deteriorated circumstances of intolerance; this study consults working journalists for collecting the empirical primary data with reference to the existence; intensity and impacts of intolerance for Press criticism in Pakistani society.

\section{Significance of the Study}

The pivotal role of the Press as a mirror of the society; as the Watchdog and as the agenda builder needs a high level of tolerance for Press criticism. It's very important to

\footnotetext{
${ }^{23}$ CPJ, "As bombing spread, Pakistan deadliest nation" (Dec15, 2010). Retrieved on October 22, 2020, from. https://cpj.org/reports/2010/12/journalists-killed-pakistan-deadliest-nation-Press/

${ }^{24}$ CPJ, "Pakistan among the countries where killers of journalists go unpunished" (Oct 29, 2020). Retrieved on October 23, 2020, from https://www.thenews.com.pk/print/736446-pakistan-among-countries-where-killersof-journalists-go-unpunished-says-cpj

${ }^{25}$ Sayeed, K. B. Collapse of parliamentary democracy in Pakistan. The Middle East Journal, 389-406. 1959

3 Yusuf, Huma, Emrys Schoemaker. "The media of Pakistan: Fostering inclusion in a fragile democracy." (Policy Briefing 9, 2013) 9-10.

${ }^{26}$ Siraj, "Critical analysis of Press freedom in Pakistan", Journal of Media and Communication Studies, $(2009$,.

$1(3), 43$.

${ }^{27}$ Hussain, Fazal, and Auj-e Kamal. "THREATS TO JOURNALISTS IN SINDH: EVENTS AND PERCEPTIONS (2000-2017)". Journal of Social Sciences and Humanities 57, no. 2 (November 12, 2020): 193-209. Accessed November 4, 2020.from, https://jsshuok.com/oj/index.php/jssh/article/view/63.
} 
empirically calculate the presence and the intensity of intolerance in Pakistani Society for local and national press. The perceived levels of intolerance for press criticism can be most accurately; found after involving working journalists in the process of research. This study is significant in this respect which is aimed to investigate the reaction against news after they are reported and disseminated. Also; this study provides reliable data for the necessary policy making in the fields of media; journalist protection and legislation.

\section{Research Methodology}

This study explores the media landscape of Pakistan to locate intolerance for Press criticism in the society. Therefore; survey method was devised with close ended questionnaire; centered on the intolerance for Press criticism in the society and focused to identify and locate the impacts of such intolerance on the objectivity of Press content.

Survey was conducted throughout Pakistan from April to September 2020; five hundred questionnaires were distributed among working journalist in Karachi; Lahore; Quetta; Peshawar; Islamabad; Rawalpindi; Mardan; Faisalabad and Malakand Press clubs and also in different media houses in the said cities of the country; under the research ethics following snow ball techniques. The survey was self-administered. The questionnaire was developed as bilingual to facilitate respondents. Three hundred and twenty questionnaires were found complete from all respects and were statistically analyzed using statistical applications of MS-Excel. The simple statistics are helpful make easy understandings for common man and provides a clear image of the situation analysis.

\section{Research Finding and Analysis}

The study is focused on the exploration of intolerance for Press criticism in Pakistan so the questionnaire is centered to collect responses of working journalists about its existence; intensity and impacts on the whole process of journalistic work. Following are the findings yielded after the statistical treatment and discussions on the results derived.

\section{Geographical Spread}

The following table summarizes the respondents from the five clusters which were devised for facilitating understandings regarding the survey.

\begin{tabular}{|c|c|c|c|c|}
\hline Cluster & Males & Females & Names. Not Provided & Total \\
\hline Sindh & 96 & 11 & 9 & 116 \\
\hline Baluchistan & 41 & 2 & 0 & 43 \\
\hline Isl+Rawalpindi & 60 & 4 & 2 & 66 \\
\hline KPK & 49 & 2 & 0 & 51 \\
\hline Punjab & 36 & 8 & 0 & 44 \\
\hline Total & 282 & 27 & 11 & 320 \\
\hline
\end{tabular}

Source: Self-created 
Interpretations: Table one show that 320 respondents were included in the survey. Working journalists from Sindh were 116; from Islamabad and Rawalpindi 66; from KPK 51; from Punjab 44 and from Baluchistan 43. Also; the table indicates that 282 male and 27 female journalists participated in the survey.

\section{Diversity in Pakistani Society: the existence}

The following figure amplifies the perceptions of journalists regarding the presence and the level of intolerance for Press criticism in the divergent society in which they are working.

Fig 1.

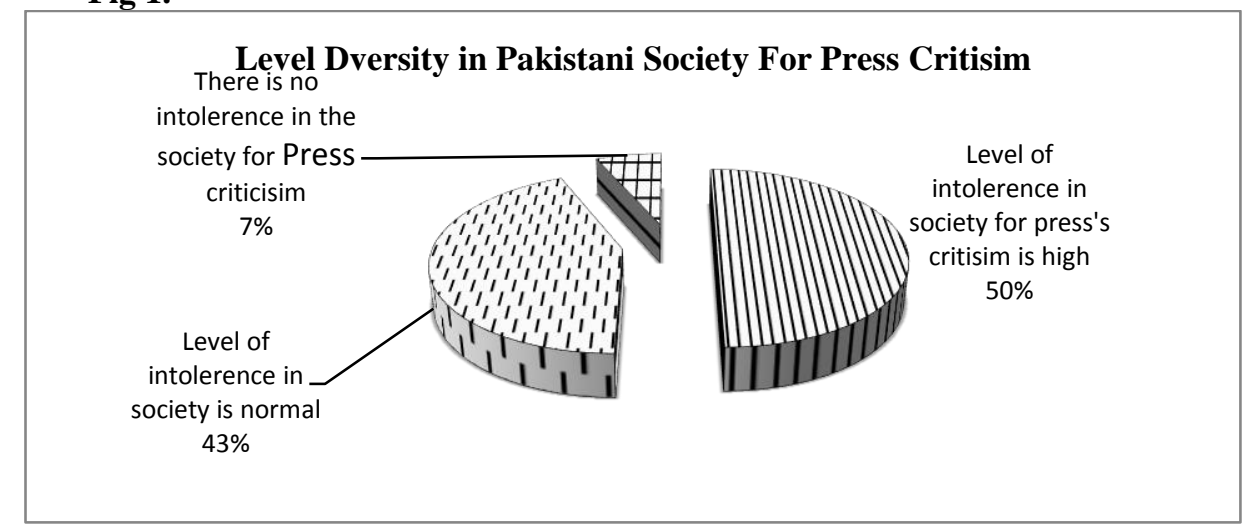

\section{Interpretation}

The figure indicates that most (50\%) of the journalists working in the field; perceive high level of intolerance in the society for Press criticism while $43 \%$ opined that level of intolerance is normal whereas only $7 \%$ denoted that there is no intolerance for Press criticism in Pakistani society.

\section{Perceived Impact of Social Diversity}

The following figure demonstrates perceptions of working journalists regarding the Perceived Impact of Social Diversity on professionalism with reference to Press freedom. 
Fig 2.

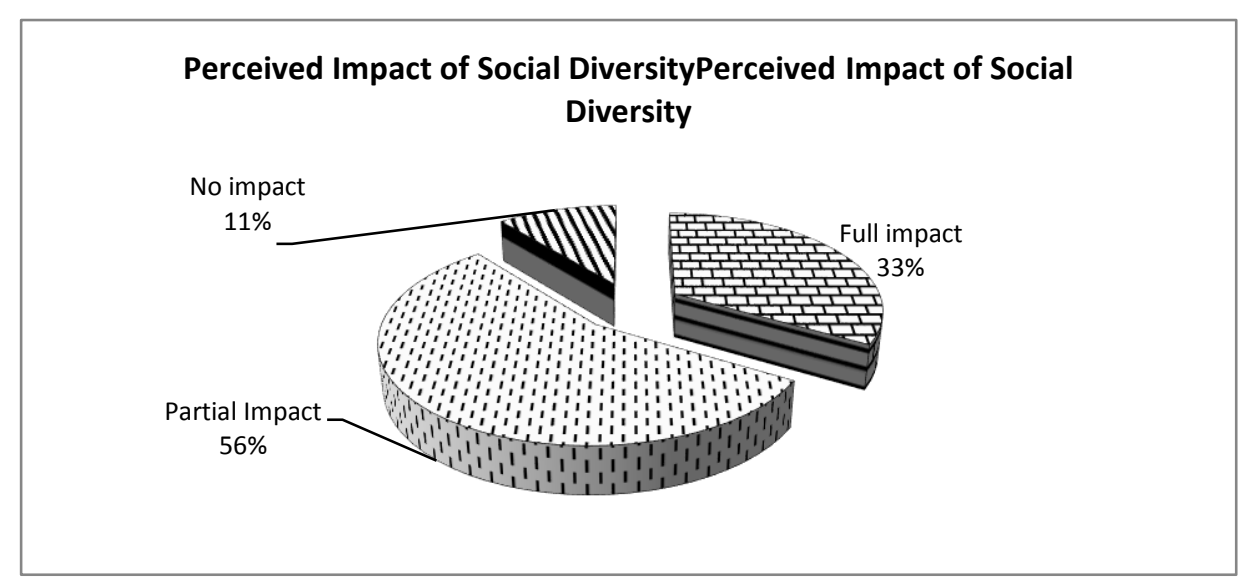

\section{Interpretations}

The figure illustrates that most (56\%) of the journalists confirm that the divergent nature of Pakistani society affects their professional activities in term of Press freedom while $33 \%$ asserts that their job is fully affected by the diverse pattern of the society whereas only $11 \%$ denied the negative impact of diversity in the society that exist in the land.

\section{Exercising Self-Censorship: to avoid threats and adverse reaction}

The following figure shows the summary of perceptions of working journalist in Pakistan about the exercise of self-censorship to avoid any adverse feedback and threats as a reaction to their professional job.

\section{Fig 3.}

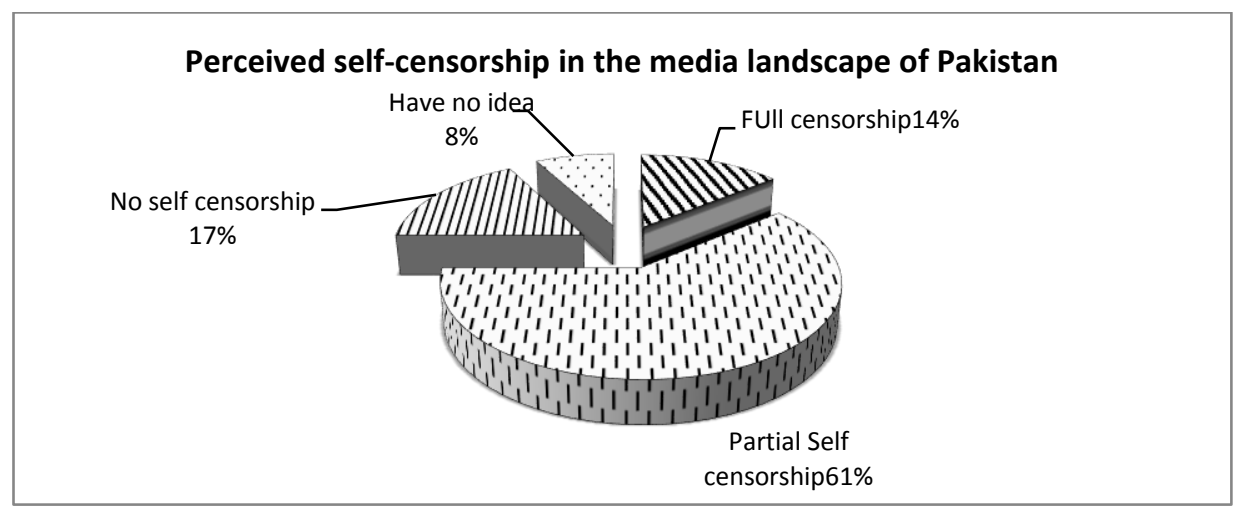




\section{Interpretations}

The figure indicates that a high majority (61\%) of the working journalist partly exercise self-censorship for their professional activities while $14 \%$ put it into full effect whereas only $17 \%$ claims that they don't practice self-censorship.

\section{Impacts of self-censorship}

The figure summarizes the perceptions of journalists regarding the negative impacts of practicing self-censorship for journalistic works.

\section{Fig 4.}

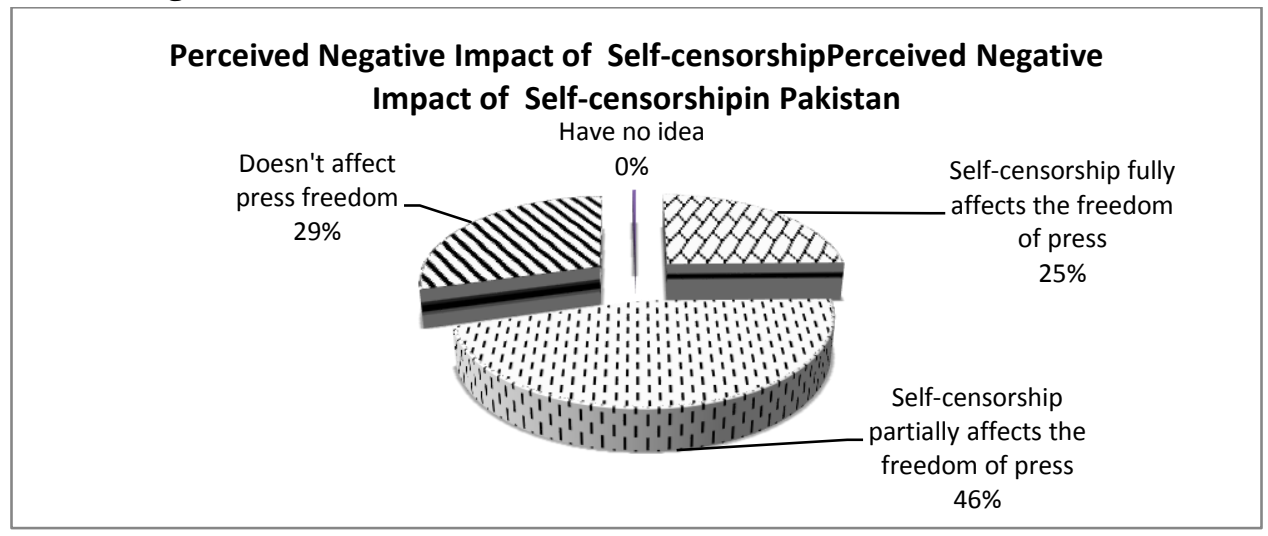

\section{Interpretations}

The figure denotes the impacts of exercising self-censorship on the freedom of Press in terms of professionalism. Most $(46 \%)$ of the journalists opined that applying selfcensorship partially affect the professional freedom while $25 \%$ affirmed fully affected scenario whereas $29 \%$ declared that exercising self-censorship doesn't affect the working conditions and objectivity of their professional jobs.

\section{The moral of working journalists}

The following figure summarizes the perceptions of working journalist about the future of Press in Pakistan even after the unfavorable working conditions and the presences of threats and negative social behavior of the society towards Press criticism. 
Fig 5.

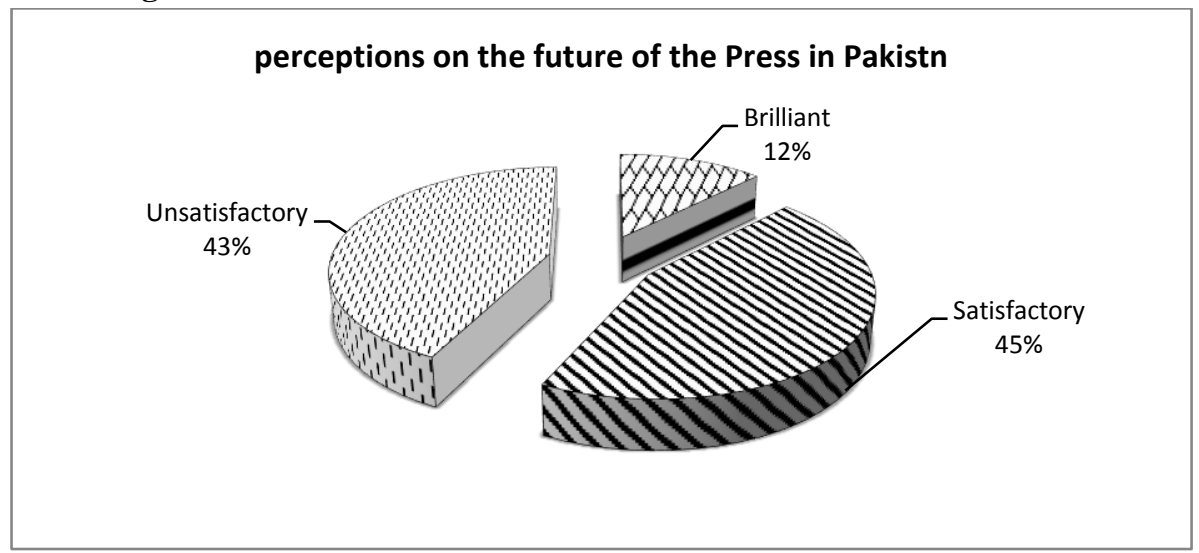

\section{Interpretations}

The figure indicates that most (45\%) of journalists are hopeful about the future of Press in Pakistan and place the situation as satisfactory while $12 \%$ consider it as brilliant where as $43 \%$ respondents are worrying about the future of Press in the country and they declare it as unsatisfactory.

\section{Discussions}

The findings of the study significantly and very clearly illustrate the presence; intensity and impacts of the intolerance for Press criticisms in Pakistani society. The perceptions and indications of working journalists who are directly facing the feedback and reaction in the society for Press criticism are the most pinpointed and validated extractions that this study has scientifically collected and summarized. The study finds that high level of intolerance in the society exists for Press criticism which was confirmed by $50 \%$ of the respondents.

It's very important to note that $50 \%$ high and $43 \%$ normal level of the intolerance for Press criticism is indicating an alarming situation for the Press to work free of threats; tension and Pressure and to play its necessary role in the development of democratic norms and values.

Similarly; the confirmation of negative and harsh impacts of intolerance for Press criticism in the Pakistani society on the professionalism in Press denotes more drastic circumstance for the freedom of expression and devastating effects for implications of objective role of the journalists as Watchdogs.

The more shocking aspect of the media environment with references to the intensity of the intolerance for Press criticism in Pakistani society is the exercise of self-censorship by working journalists. The findings indicate that a remarkable percentage $(61 \%$ partly and $14 \%$ fully) of working journalists exercise self-censorship to avoid the adverse reaction due the presence of intolerance for Press criticism in the society. The most 
dangerous scenario is that journalist censor their job accordingly while knowing that treating their work in such a way is unprofessional and is havoc to the objectivity of professionalism. But they justify it for their security and safety because they are not satisfied with the existing low level of rule of law and about the deteriorated conditions of law and order situation in the country.

Even then; working journalists are brave enough to handle the situation by self and continuously working in a state of fear and distrust and it's understandable in the sense that journalists in Pakistan has a firm belief that Allah has to protect them and so they are hopeful about the situation to be better in future.

\section{Conclusion}

The highly diverse society and low level of the rule of law always lead to uneasy violent response to criticism. Similarly; the low educational level and the high frustration in the society leave narrow space for the Press to work professionally. In the same way the political affiliations of journalists give chance to be polarized and as a result intolerance for Press criticism proliferates. This study proves that a high level of intolerance exists in Pakistani society for Press criticism and also it establishes that such an intolerance badly affects the objectivity of Press. The study also indicates that most of the journalists exercise self-censorship to avoid the negative impacts; the unsympathetic violent reaction and adverse reaction to Press criticism by the society. But the dogmatism of working journalists which this study extracted is encouraging where journalists are hopeful about the future of the Press in Pakistan to be bright and the situation will be favorable in terms of intolerance for Press criticism in the society.

\section{Recommendations}

On the basis of findings; this study suggests the following measures to be taken to diminish intolerance for Press criticism in Pakistani society.

1. It's highly recommended to develop social dialogue for the awareness of the role of Press as a Watchdog to safeguard the rights of citizen and hold those in power accountable.

2. Security and safety measures for the protection of working journalists are necessary to be devised on governmental level to encourage journalist for their professional duties.

3. Swift Complaint and Redressal mechanism should be planned to assure safe conditions for professional working.

4. Multiple dimensional forums should be organized to work for making the society media friendly. 


\section{Bibliography}

Asma and Muhammad;"History of Sectarianism in Pakistan: Implications for Lasting Peace: J Pol Sci Pub Aff 2017; 5:4 ; DOI: 10.4172/2332-0761.1000291;

https://www.longdom.org/open-access/history-of-sectarianism-in-pakistan-implicationsfor-lasting-peace-2332-0761-1000291.pdf

Basit. Abdul; ; "Pakistan Stock Exchange: New Wave of Ethno-Separatist Violence?; South Asian Journal; (July 17; 2020); http://southasiajournal.net/pakistan-stockexchange-attack-new-wave-of-ethno-separatist-violence/

Chiara V; Ramon Portugal F; Jeanson R "Social intolerance is a consequence; not a cause; of dispersal in spiders". (2019) PLoS Biol 17(7): e3000319.

https://doi.org/10.1371/journal.pbio.3000319

Constitution of Pakistan 1973; Chapter 1; article 19; 19A.

http://www.na.gov.pk/uploads/documents/1333523681_951.pdf

CPJ; "As bombing spread; Pakistan deadliest nation" (Dec15; 2010).

https://cpj.org/reports/2010/12/journalists-killed-pakistan-deadliest-nation-Press/

CPJ; "Pakistan among the countries where killers of journalists go unpunished" (Oct 29; 2020). https://www.thenews.com.pk/print/736446-pakistan-among-countries-wherekillers-of-journalists-go-unpunished-says-cpj

Daily Dawn; "50 shades of inequality in Pakistan"; (May 14; 2015);

https://www.dawn.com/news/1178703

Daily Dawn; "Peshawar Press Club Attack (Dec 12; 2009). https://www.dawn.com/news/510394

Daily Dawn; “Sectarian Tensions' Sep 21; 2020. https://www.dawn.com/news/1580818

Daily Dawn. "A leaf from history: Language frenzy in Sindh" Oct 6; 2012.

https://www.dawn.com/news/754685/a-leaf-from-history-language-frenzy-in-sindh

Freedom House. https://freedomhouse.org/countries/freedom-world/scores

Gunaratne; Shelton A. "The Media in Asia: An Overview." Gazette (Leiden;

Netherlands) 61; no. 3-4 (July 1999): 197-

223. https://doi.org/10.1177/0016549299061003002.

Harrison G. Gough "Studies of Social Intolerance: I. Some Psychological and Sociological Correlates of Anti-Semitism; The Journal of Social Psychology"; (1951) 33:2; 237-246; DOI: 10.1080/00224545.1951.9921815 
Hussain; Fazal; and Auj-e Kamal. "THREATS TO JOURNALISTS IN SINDH: EVENTS AND PERCEPTIONS (2000-2017)". Journal of Social Sciences and Humanities 57; no. 2 (November 12; 2020): 193-209. Accessed December 4; 2020. https://jsshuok.com/oj/index.php/jssh/article/view/63.

Hussain; Fazal. "Gender Discrimination in Media As Workplace: A Study of Media Environment in Sindh". Pakistan Journal of Gender Studies 18; no. 1 (March 8; 2019): 23-42. Accessed December 4; 2020. https://www.socialsciencejournals.pjgsws.com/index.php/PJGS/article/view/23.

Hutchison; Marc L.; Salvatore Schiano; and Jenifer Whitten-Woodring. "When the fourth estate becomes a fifth column: The effect of media freedom and social intolerance on civil conflict." The International Journal of Press/Politics 21; no. 2 (2016): 165-187. https://doi.org/10.1177/1940161216632362

Hutchison; Marc L.; Salvatore Schiano; and Jenifer Whitten-Woodring. "When the fourth estate becomes a fifth column: The effect of media freedom and social intolerance on civil conflict." The International Journal of Press/Politics 21; no. 2 (2016): 165-187. https://doi.org/10.1177/1940161216632362

Mustafa.Ghulam \& Nawa.Adil. "The Separation of East Pakistan: Socio-Economic Factors" Asian Journal of Multidisciplinary Studies. Vol 2; issue 1 (2014).

https://www.academia.edu/42789130/Asian_Journal_of_Multidisciplinary_Studies_The _Separation_Of_East_Pakistan_Socio_Economic_Factors

Pakistan Bureau of Statistics (2016) ." Population by Mother Tongue" http://www.pbs.gov.pk/sites/default/files//tables/POPULATION\%20BY\%20MOTHER \%20TONGUE.pdf

PBS; "Population by Religion"

http://www.pbs.gov.pk/sites/default/files//tables/POPULATION\%20BY\%20RELIGION .pdf

The Nation; "Hooligans attack Karachi Press Club".( March 28; 2016). https://nation.com.pk/28-Mar-2016/hooligans-attack-karachi-Press-club

Universal Declaration of Human Rights (1948). https://www.un.org/en/universaldeclaration-human-rights/

Wyatt. Wendy. "Press Criticism" in: The International Encyclopedia of Journalism Studies Online.

https://onlinelibrary.wiley.com/doi/pdf/10.1002/9781118841570.iejs0104 